\title{
Richness of drilling sludge taken from an oil field quagmire: potentiality and environmental interest
}

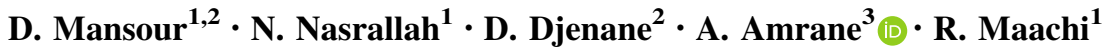

Received: 30 October 2015/Revised: 29 March 2016/Accepted: 19 July 2016/Published online: 10 August 2016

(C) Islamic Azad University (IAU) 2016

\begin{abstract}
The drilling sludge represents a complex environment, containing several types of pollutants that can be even used as nutrients by indigenous microorganisms, like hydrocarbon-degrading bacteria, having good potentialities for the biodegradation of petroleum products. In this study, a drilling sludge was collected from drilling quagmire. Physicochemical characterization of the drilling sludge was done. Its mineralogy was obtained by diffractometry. The indigenous aerobic sludge hydrocarbon-degrading bacteria were checked by counting on Bushnell-Haas medium, and their isolation and purification were performed by the selective microbial enrichment technique in a batch-enriched Bushnell-Haas culture, with crude oil as the sole carbon source. Isolates were characterized, and their power to emulsify crude oil was determined by emulsification index and oil spreading tests. Environmental conditions in the quagmire, like temperature, $\mathrm{pH}$ and moisture, were suitable for bacterial development. Physicochemical characteristics of the drilling sludge showed richness in chemical elements and promote microbial life. Fifteen different colonies of hydrocarbon-degrading bacteria were isolated and purified; they have diversified morphological and
\end{abstract}

A. Amrane

abdeltif.amrane@univ-rennes1.fr

1 Laboratory of Chemical Reaction Engineering, Faculty of Mechanical Engineering and Process Engineering, University of Sciences and Technology Houari Boumediene, BP 32, 16111 Algiers, Algeria

2 Laboratory of Food Quality and Food Safety, Faculty of Biological and Agricultural Sciences, Mouloud Mammeri University, BP 17, 15000 Tizi-Ouzou, Algeria

3 Ecole Nationale Supérieure de Chimie de Rennes, CNRS, UMR 6226, Avenue du Général Leclerc, CS 50837, 35708 Rennes Cedex 7, France microscopic aspects. Most isolates had a good emulsification index (between 31 and $76 \%$ ). Oil spreading test gave clear zone diameters $>28 \mathrm{~mm}$, with a maximum of $60 \mathrm{~mm}$. The results of these investigations prove the elementary, mineralogy and microbiology richness of drilling sludge and reveal the high diversity of its indigenous hydrocarbon-degrading bacterial flora. These properties can be exploited for the own restoration of petroleum quagmires in oil fields, by means of bioremediation applications and by integrating indigenous microorganisms.

Keywords Bioremediation - Drilling sludge · Hydrocarbon-degrading bacteria $\cdot$ Petroleum industry pollution - Physicochemical characterization - Sustainable environment

\section{Introduction}

The drilling petroleum activities generate hydrocarbon wastes, whose deep penetration from the topsoil into the subsoil presents a direct risk of environment, groundwater and ecosystems contamination (Osman 2014; Baba Hamed 2013). Oil companies are taking steps designed to register their drilling activities with a view of sustainable development, consisting to ensure production, and also to protect the environment (Escobar and Vredenburg 2011).

The onshore drilling discharges correspond to drilling wastes including drilling fluids, commonly called "drilling muds" and cuttings, as well as the produced water (Doyle et al. 2008). Downstream of the drilling process, the settling of sludge in sealed pits gives recyclable drilling water and a solid fraction either put into controlled dumps or processed for use as backfill material 
(Wojtanowicz 2016). Three of the primary functions that drilling muds perform are lubricating and cooling the drilling bit, maintaining downhole hydrostatic pressure and cleaning out the hole by bringing cuttings to the surface with less viscosity (Smagin et al. 2011). For ensuring these roles, drilling fluids are added to weighting agents such as barium sulfate or iron (III) oxide to increase the density of the mud, clays or polymers to adjust viscosity, and chemicals to increase lubricity, caustic soda/lime to control the $\mathrm{pH}$, plus other minor additives used to more precisely control the mud properties (Caenn et al. 2011; Johannes 2012).

During storage in a drilling quagmire, drilling mud contents, especially hydrocarbons, undergo a series of changes and generate pollution risk, as a result of their complex composition. Practically, multiple physicochemical processes are used in the treatment of drilling quagmires (thermal treatment, dig and dump method, separation techniques, stabilization-solidification technology, chemical method), but these have a high cost and are not environmentally friendly (Shperber et al. 2011; Egazar'yants et al. 2015), in contrary of microbial degradation which seems a solution, showing to be efficient, clean and low-cost process, even if it is, however, slow (Semple et al. 2003; Bidoia et al. 2010). In fact, paralleled to their harmfulness, drilling wastes can present a positive impact, such as plant productivity which is due to the optimization of physical and agrochemical properties of drilling muds (Shagut and Ignat'ev 2012), or landfarmed oil sludge use as a carbon source in phytoremediation processes of oily soils (Ramirez and Dussan 2014; Nanekar et al. 2015), and other ecological and economical uses (Shperber, Bokovikova and Shperber 2011). Oil sludge is a complex mixture of petroleum products (alkanes, aromatic hydrocarbons, etc.), NSO (nitrogensulfur-oxygen)-containing compounds, asphaltene fractions and other useful elements (Mansurov et al. 2001; Beskoski et al. 2011), and this composition makes them a physicochemically and organically very conducive environment to the living world; bacteria and fungi find in such environment the appropriate nutritional requirements for their development. Consequently, the use of effective biological processes in situ and on site, such as vermiculture, phytoremediation, land farming, composting and ex situ bioreactors to improve the rate of contaminant removal, contributes to the cleanup of hydrocarbon-polluted compartments, by using even autochthon microbial flora (McDonald and Portier 2003; Atagana 2008; Osman 2014). In such biological processes, biosurfacants play an important role; they are surface-active compounds of biological origin secreted in the environment to facilitate the diffusion and uptake of hydrophobic substances (Kang et al. 2010; Lawniczak et al. 2013). The knowledge of the physical properties and mineral availability of the drilling sludge, its composition in indigenous bacterial populations, their biodegradation capacities and the bioavailability of organic pollutants, can facilitate decisions on the efficacy of biotreatment techniques of the quagmire and determine the attainable treatment end-points (Korol et al. 2005). Biological methods for detoxifying oily sludge are some of the most environmentally friendly approaches, but the range of their applications is function of their activity range, the obligate adaptation to the surrounding site conditions and the medium's properties (Egazar'yants et al. 2015). Environmental factors such as soil type and structure; $\mathrm{pH}$; temperature; moisture and the presence of adequate levels of nutrients and oligoelements for the activity of the oil-degrading microbial community should be kept in mind, while remediating petroleumpolluted site, such as a quagmire (Bamforth and Singleton 2005). This work was realized in this context, during the years 2011 and 2012 at the laboratories of Sonatrach (Algerian Oil Company). Drilling sludge samples were taken from a quagmire located in an Algerian oil field, and several characterizations were made, in order to find correlations between the composition of the sludge, the availability of organic and mineral compounds and indigenous hydrocarbon-degrading flora. This flora was isolated and tested for its ability to biodegrade hydrocarbons. The physicochemical and biological composition of drilling sludge can be exploited for its treatment by bioremediation, and consequently, drilling muds can provide the solution to their own risk pollution, as well as to similar pollution problems.

\section{Materials and methods}

\section{Drilling sludge sampling}

Three punctual samples ( $250 \mathrm{~g}$ ) of a drilling sludge were taken from an eight-year-aged drilling quagmire (when sampled), in an oil field located in the south of Algeria, specifically in the Saharan region located $800 \mathrm{~km}$ southeast of the capital Algiers, by a systematic random sampling according to grids method and site's temperature was taken (Huesemann 1994; ISO 5667-13 1997; Singh et al. 2005). After removing the surface soil $(2-3 \mathrm{~cm})$, samples were taken at a depth of about $10 \mathrm{~cm}$ from the surface, using sterile sampling tools and glass containers. They were stoppered, sealed, labeled, covered with aluminum foil and placed in a cooler. Once at the laboratory, samples were thoroughly and aseptically mixed, giving a single representative sample, which was kept in the dark at $4 \pm 2{ }^{\circ} \mathrm{C}$ and pulled out $4 \mathrm{~h}$, before handling it for microbiological purposes. 


\section{Crude oil origin}

The crude oil used was taken from oil-producing well located in the same drilling mud sampling area. Its sterilization was done by vacuum filtration through $0.45-\mu \mathrm{m}$ filters.

\section{Physicochemical characterization}

The moisture content of the drilling sludge was determined by the gravimetric method, applied on the solid matrix (ISO 11461 1997). In order to characterize the collected sludge, leaching tests were performed (AFNOR NF X 31-210 1993; AFNOR NF EN 12457-2 2002), and then its pH was measured using a HACH sensION 3 pHmeter from Hach Lange (Lognes, France) (ISO 10390 2005). Sodium and potassium concentrations were determined by ZEEnit 700P flame emission spectrometer, from AnalytikJena AG (Jena, Germany) (AFNOR NF T 90-019 1984); calcium and magnesium (NF EN ISO 7980 2000), zinc in sediments (NF ISO 11464 (X31-412) 2006; NF X 31147 1997) and heavy metals (FD T90-112 1998), were determined by atomic absorption spectrometry. Concentrations were expressed, in $\mathrm{mg} / \mathrm{kg}$ and ZEEnit 700P atomic absorption spectrometer from Analytik Jena AG (Jena, Germany), driven by a WinAAS operating system, version 3.17.0, was used.

The total hydrocarbon content was determined by the hydrocarbon extraction method in acid medium, and then the absorbance was measured in a wavelength interval from 2900 to $3100 \mathrm{~cm}^{-1}$ (AFNOR NF T 90-114 1979; Touraud et al. 2007), using an infrared spectrometer-type MAGNA-IR Spectrometer-Nicolet 560 from Nicolet Instrument Corporation (Madison, Wisconsin, USA), with a resolution of $4 \mathrm{~cm}^{-1}$ and a number of sweeps equal to 5 . The hydrocarbon content was expressed in $\mathrm{mg} / \mathrm{kg}$. Total organic carbon (TOC) was measured by a calcination method of the solid matrix (ISO 10694 1995), using a TOC LECO WR112-Carbon Determination (LECO Corporation St. Joseph apparatus, Michigan, USA), and the carbon concentration was given in $\mathrm{g} / \mathrm{kg}$.

The mineralogy of the drilling oily sludge was obtained by determining the mineral phases of the solid matrix, by the powder method of X-ray diffraction, using a PANalytical XPERT PRO diffractometer from PANanalytical B.V (Almelo, Netherlands), equipped with a ceramic ray tube with copper anticathode, and an RX power generator $(40 \mathrm{~mA}, 45 \mathrm{kV})$. Data acquisition and data processing are obtained by using Data Collector PANalytical and PANalytical HighScore Plus softwares.

\section{Biological characterization}

Bacterial numeration of the indigenous aerobic oil-degrading bacteria was done on Bushnell-Haas (BH) medium (Bushnell and Haas 1941), by the plate count technique. Ten grams of the drilling sludge sample with $100 \mathrm{ml}$ of $\mathrm{BH}$ medium is rapidly stirred (for $2-3 \mathrm{~min}$ ) at $150 \mathrm{rpm}$, and then, a series of dilutions up to $10^{-10}$ were prepared in physiological sterile water. One hundred microliters of each dilution was inoculated by spreading on solid $\mathrm{BH}$ medium in triplicate and incubated at $30^{\circ} \mathrm{C}$ in Memmert IN30 incubator (Memmert GmbH, Schwabach, Germany), until the number of colonies was constant (for 24-72 h). The colony count was done using a scan100 manual colony counter from Interscience (Saint Nom, France) and expressed in CFU/ml (Foght and Aislabie 2005).

Isolation and purification of biodegrading aerobic bacteria (HDB) was done by the selective microbial enrichment technique using a batch-enriched $\mathrm{BH}$ culture (Vecchili et al. 1990; Singh et al. 2005; Overmann 2013). Ten grams of the drilling sludge sample, $100 \mathrm{ml}$ of $\mathrm{BH}$ medium and $1 \%$ sterile crude oil (Calvo et al. 2008) were mixed with $10 \%$ sterile extract of the mire (Claus et al. 2006) and incubated at $30{ }^{\circ} \mathrm{C}$ for $4-7$ days (Calvo et al. 2008), under continuous stirring at $150 \mathrm{rpm}$ in a Thermoshake Gerhardt shaker incubator (C. Gerhardt GmbH \& Co. KG·Analytical Systems, Königswinter, Germany). One hundred microliters of the prepared culture was seeded by plating on BH solid medium, containing $1 \%$ sterile crude oil (Déziel et al. 1996) and $10 \%$ sterile extract of the slough and incubated at $30^{\circ} \mathrm{C}$ for $24-48 \mathrm{~h}$. Bacterial purification, based on colony morphology, was obtained after at least three cycles of streaking, and strains' characterization was ensured, by traditional microbiological methods and biochemical standard procedures (Gerhardt et al. 1981).

\section{Ability of bacterial isolates to hydrocarbon biodegradation}

\section{Emulsification index}

The power of the isolates to emulsify water-immiscible compounds, such as crude oil, was determined in terms of their emulsification index (E24) (Cooper and Goldenberg 1987; Banat 1995). In a test tube, 20 hundred microliters of the culture broth, at late exponential phase, added to an equal volume of the crude oil were vortexed at high speed for 2 min using a mini vortex mixer (Fisher Scientific, France); then, the test tube was kept for $24 \mathrm{~h}$ at ambient temperature and atmospheric pressure. The emulsification index was calculated by dividing the measured height of the emulsion layer by the height of the total mixture and multiplying by 100 (Iqbal et al. 1994). The emulsion was observed by using ZEISS-AXIOSKOP optical microscope (Carl Zeiss Group, Jena, Germany). 


\section{Displacement test}

The oil spreading test measures the diameter of clear zones caused when a drop of a biosurfactant-containing culture is placed on an oil-water surface. The binomial diameter allows the determination of the cleaning efficiency of the tested biosurfactant-containing culture. The oil spread technique was carried out by adding $50 \mathrm{ml}$ of distilled water in Petri dish, followed by addition of $200 \mu \mathrm{L}$ of crude oil to the surface of the water. Then, $20 \mu \mathrm{L}$ of the bacterial culture was dropped on the center of the crude oil surface. The diameters of clear zones on the oil surface of triplicate assays from the same sample were measured after $30 \mathrm{~s}$ by comparing to distilled water as negative control (Youssef et al. 2004).

\section{Results and discussion}

The studied quagmire received the drilling muds of an oil producer well drilling operation, carried out in five phases between 31/12/03 and 26/02/2004, by using classic system of oil-based mud (OBM) (Table 1). The drilling sludge collected presented sandy and stiff consistency, coward compactness, and its hydrocarbon contamination was visually moderate with average odor. The temperature in site coincided with the normal of seasonal average in the Saharan region, so allowing mesophilic bacteria development. The maximum metabolic activity of microorganisms is generally observed between 30 and $40{ }^{\circ} \mathrm{C}$ (Normand et al. 2015), namely in the range of temperatures observed in the south regions of Algeria; the highest hydrocarbon degradation rates generally occur in the range of $30-40{ }^{\circ} \mathrm{C}$ in soil environments (Chandra et al. 2013). Moreover,

Table 1 General data of the quagmire

\begin{tabular}{ll}
\hline Parameters & Data \\
\hline Zone & Southeast of Algeria \\
Dimensions $(\mathrm{m})$ & $25.5 \times 18.5 \times 3$ \\
Drilling phases of the & A: phase $26^{\prime \prime}: 25.12 .2003-30.12 .2003$ \\
corresponding well & $(473 \mathrm{~m})($ Versa drill Relaxed mud) \\
& B: phase $16^{\prime \prime}: 31.12 .03-11.01 .2004$ \\
& $(2277$ m) $($ OBM mud $)$ \\
& C: phase $12^{1 / 4^{\prime \prime}:}$ \\
& $12.01 .2004-28.01 .2004(3327 \mathrm{~m})$ \\
& $($ OBM mud $)$ \\
& D: phase $83 / 8^{\prime \prime}:$ \\
& $29.01 .2004-07.02 .2004(3507 \mathrm{~m})$ \\
& $($ OBM mud $)$ \\
Ehysical, thermal, chemical, & Nothingness (between drilling and $6^{\prime \prime}: 08.02 .2004-26.02 .2004$ \\
biological treatments & sampling operations) \\
\hline
\end{tabular}

temperature influences the biodegradation of oil by altering its physical state (viscosity, volatility, solubility) and chemical composition and by interfering with the physiological activity, the diversity and the concentration of microbial species (Yadav et al. 2012).

The $\mathrm{pH}$ was slightly above neutrality (Table 2), which can be related to the previous $\mathrm{NaOH}$ addition in the drilling fluid, with the aim to control the solubility of certain salts and to reduce the corrosion of metallic elements (Johannes 2012). However, this value remained significantly lower than sludge's pH (9.5-10.5), which can be explained by the telluric flora metabolism or the addition of acid chemical compounds. This $\mathrm{pH}$ coincides with the best physiological $\mathrm{pH}$ required by most heterotrophic bacteria and fungi, which prefer a $\mathrm{pH}$ near neutral (Chandra et al. 2013). The quagmire appeared to be relatively humid $(6.73 \%)$; its moisture content is function of the climate and the retentive properties of the matrix. Moisture is an important factor for microorganisms' growth and plays a determinant role in biodegradation of hydrocarbon-contaminated soils. A minimal amount of water is needed to make effective solubilization of petroleum hydrocarbons and maintain sufficient moisture for growth. Thus, it influences air permeability in soil and consequently oxygen distribution. Microbes live in the interstitial water of soil pores, and thus, a lower amount of water means that a smaller number of microbes are present and consequently the removal rate through biodegradation is slower (Chandra et al. 2013).

The content of total hydrocarbons in the quagmire was relatively significant $(5.5 \mathrm{mg} / \mathrm{kg})$, as well as its total organic carbon content $(7.7 \mathrm{~g} / \mathrm{kg})$, even after 8 years of drilling (from the beginning of the drilling operation in 2003 to the sampling date in 2011). Hydrocarbons came from the base fluid used in OBM that is a petroleum product, additionally to the formation oil returned in the produced water. It can be noted that weathering phenomena (volatilization, photooxidation, etc.) and biodegradation are the factors which can reduce the hydrocarbon content of soil after crude oil contamination (Semple et al. 2003). Hydrocarbon properties that influence their biodegradation in a polluted environment can include their aqueous solubility and volatility, their molecular weight and complexity, octanol-water coefficient, cell toxicity, their physical

Table 2 Physicochemical characteristics of the drilling sludge

\begin{tabular}{ll}
\hline Parameters & Data \\
\hline Temperature $\left({ }^{\circ} \mathrm{C}\right)$ & $23-26$ \\
$\mathrm{pH}$ & 7.31 \\
Moisture $(\%)$ & 6.73 \\
TOC (total organic carbon) $(\mathrm{g} / \mathrm{kg})$ & 2.68 \\
Hydrocarbon content $(\mathrm{mg} / \mathrm{kg})$ & 15.5 \\
\hline
\end{tabular}


state in situ, surface area of hydrocarbon phase and the presence of other organic compounds in the same media where competitiveness can occur (Abbasnezhad et al. 2011)

In general, the main environmental parameters that affect biodegradation of hydrocarbons to bioremediate contaminated soil or even water include $\mathrm{pH}$, temperature, water availability, surface area and sorptive surfaces, nutrients availability, redox conditions and the presence of toxic compounds (Abbasnezhad et al. 2011; Mohanty and Mukherji 2012).

By analyzing the chemical composition of the drilling mud sample, important concentrations of alkaline earth metals was revealed ( 21.100 and $3.816 \mathrm{~g} / \mathrm{kg}$ of $\mathrm{Ca}$ and $\mathrm{Mg}$, respectively); these elements play a vital role in microorganism's growth. Usually, metallic cations $(\mathrm{Ca}, \mathrm{Mg}, \mathrm{K}$ and $\mathrm{Na}$ ) are fixed in large quantities by soil particles, unlike others, as oligoelements ( $\mathrm{Mn}, \mathrm{Zn}, \mathrm{Cu}$ ) in more limited quantities, which is consistent with the results of analyses. Indeed, $\mathrm{Ni}, \mathrm{Co}$ and $\mathrm{Cd}$ concentrations were not representative, and those of $\mathrm{Pb}, \mathrm{Cr}$ and $\mathrm{Li}$ were $46.8,17.8$ and $9.0 \mathrm{mg} / \mathrm{kg}$, respectively (Table 3). These metals are generally present in the composition of drilling sludge (Agwa et al. 2013; Reyes-Avila et al. 2013). Ion and metal richness can be native to the solid matrix mineral dissolution, rain water or produced water. Indeed, besides its ionic constituents; produced water may contain dissolved and dispersed organic compounds, including oxygen-, nitrogenand sulfur-containing compounds, and small concentrations of heavy metals (Doyle et al. 2008). These chemical properties are relative to the fact that the produced water generated from the oil extraction process includes the native formation water, the injected water, and various added solutions and chemicals for well treatment (Doyle

Table 3 Heavy metal and alkaline earth metal concentrations in the drilling sludge

\begin{tabular}{ll}
\hline Parameters & Concentration $(\mathrm{mg} / \mathrm{kg})$ \\
\hline $\mathrm{Cu}$ & 23.6 \\
$\mathrm{Ni}$ & $<2$ \\
$\mathrm{~Pb}$ & 46.8 \\
$\mathrm{Zn}$ & 90 \\
$\mathrm{Cd}$ & $<2$ \\
$\mathrm{Cr}$ & 17.8 \\
$\mathrm{Co}$ & $<2$ \\
$\mathrm{Li}$ & 9 \\
$\mathrm{Na}$ & 3146 \\
$\mathrm{~K}$ & 5046 \\
$\mathrm{Ca}$ & 21,100 \\
$\mathrm{Mg}$ & 3816 \\
$\mathrm{Mn}$ & 78.2 \\
\hline
\end{tabular}

et al. 2008). Indeed, in the process of oil and gas drilling, some additives contain a lot of heavy metals such as chrome and zinc, bringing an amount of $\mathrm{Cr}$ and $\mathrm{Zn}$ in the drilling sludge ( $\mathrm{Li}$ et al. 2011). Particularly, barite as drilling mud additive contains traces of heavy metals and it has been described some correlation between concentrations of $\mathrm{Cd}$ and $\mathrm{Hg}$, and the concentrations of some other trace metals in the barite (Agwa et al. 2013). Moreover, metal availability can be influenced by microorganisms, which modify their speciation through oxidation and reduction processes. Some microorganisms can reduce metals and hence contribute to decrease their solubility and therefore their availability and consequently their toxicity (Buekers 2007).

Mineralogy of the drilling sludge sample revealed several phases, with the estimated corresponding contents: quartz $\left(\mathrm{SiO}_{2}\right)(65 \%)$, carbonate in form of calcite $\left(\mathrm{CaCO}_{3}\right)$ (7\%), gypsum $\left(\mathrm{CaSO}_{4} \cdot 2 \mathrm{H}_{2} \mathrm{O}\right)(2 \%)$, feldspars in form of orthoclase $\left(\mathrm{KAlSi}_{3} \mathrm{O}_{8}\right)(3 \%)$, halite $(\mathrm{NaCl})(1 \%)$, illite $\left(\mathrm{KH}_{3} \mathrm{O}\right)(\mathrm{AlMgFe}) 2(\mathrm{SiAl}) 4 \mathrm{O}_{10}\left[(\mathrm{OH})_{2},\left(\mathrm{H}_{2} \mathrm{O}\right)\right](1-2 \%)$, albite $\left(\mathrm{NaAlSi}_{3} \mathrm{O}_{8}\right)(1 \%)$, barite $\left(\mathrm{BaSO}_{4}\right)(3 \%)$, dehydrated calcium sulfate in the form of anhydrite $\left(\mathrm{CaSO}_{4}\right)$ $(3 \%)$ and vaterite $\left(\mathrm{CaCO}_{3}\right)(3 \%)$ (Fig. 1). This composition describes a sandstone facies, composed essentially of quartz (Götte and Richter 2007) and incidentally other minerals constituting rock mineral paragenesis (excepted barite) and/or elements of drilling fluid. Illite which is clay can result from feldspars alteration, as for albite. For the salt crystallized in the form of halite, it can also come from the saline formation water, and from its use as controller of alkalinity and brine in drilling fluid. Carbonate of calcium is used as mineral additive in drilling mud as weighting and as filtration control agent. A small amount of calcium ions is beneficial to most drilling systems, acting as buffer against undesirable carbonate alkalinity during drilling operation. The presence of barite is explained by the use of this mineral known by its density, as weighting agent to increase the overall density of OBM, so that the downhole pressure is sufficient (Wang et al. 2015). The estimation of phase content is approximate, given the background noise which is probably due to the noncrystalline amorphous organic fraction of the drilling mud, which, by its presence, may affect the crystallization of minerals or may induce the nonappearance of their peaks when they are at low concentrations.

The bacterial count on $\mathrm{BH}$ medium of the indigenous aerobic oil-degrading bacteria or hydrocarbon-degrading bacteria in the drilling sludge sample gave $9.933 \times 10^{5} \mathrm{CFU} / \mathrm{g}$. Since the counting technique was based on oil-degrading bacteria selectivity, this result informed on the presence of hydrocarbon-utilizing bacteria in the oily sludge, and even on its richness in HDB. This finding was supported by that obtained in the enriched 


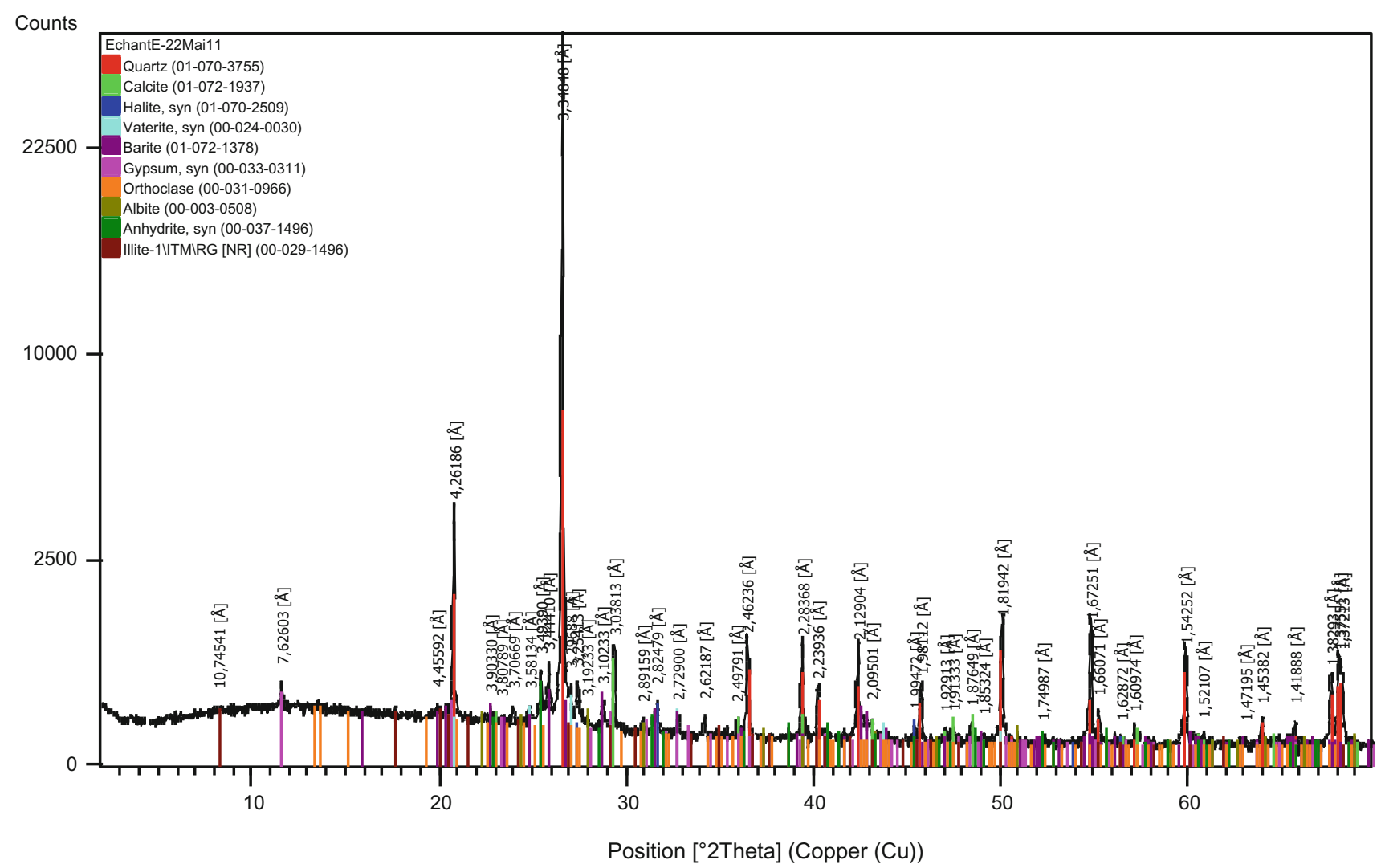

Fig. 1 X-ray diffraction patterns of the drilling sludge sample

media, where 15 different colonies were differentiated and their characterization revealed morphological, microscopic and biochemical diversities (Table 4). All isolated strains were Gram negative, and most of them were motility positive. Therefore, these microorganisms are adapted to live with hydrophobic compounds as petroleum products, as the sole carbon source. It has been proved that hydrocarbon addition in soil is followed by an increase in microbial population (Minai-Tehrani and Herfatmanesh 2007), indicating a positive correlation between the oil content and the presence of hydrocarbon-utilizing microflora. In addition, these indigenous microbial populations could be highly adapted to the toxic effects of petroleum or its degradation products (Wesp et al. 2000). It is noteworthy that this significant amount of indigenous microorganisms favored in situ biological treatment processes of the drilling quagmire, which has been proved by previous works that showed the feasibility of hydrocarbon biodegradation of oil sludge by the native microbiota (Reyes-Avila et al. 2013). It has been noted that the microbial properties affecting biodegradation of hydrocarbons concern genetic complement and the expression and regulation of microbial genes, surface hydrophobicity, metabolic diversity and flexibility, substrate uptake or adherence mechanisms, tolerance to solvent effects, adaptation to environmental conditions and competition with other microbes belonging to the same flora (Abbasnezhad et al. 2011).

Data obtained from emulsification and oil spreading tests are shown in Table 5. The ability to maintain at least $50 \%$ of the original emulsion volume $24 \mathrm{~h}$ after formation confirms the emulsion-stabilizing capacity (Banat et al. 2010), and oil spreading test is an indirect measurement of surface activity against oil; a larger diameter indicates a higher surface activity of the testing bacterial strain. Isolates S13, S18, S20, S21 and S22 had the highest values of emulsification index and displacement test, and the results indicate the relationship between cell surface hydrophobicity and emulsification activity. The E24 values were comprised between 31 and $76 \%$, and a high number of strains emulsified crude oil above $49 \%$, with the lowest emulsification index obtained with the $E_{\mathrm{F}}$ strain. The microscopic observation of the emulsified oil showed fine droplet formation (Fig. 2). Clear zone diameters in oil spreading tests were in the range $28-60 \mathrm{~mm}$, with an average oil displacement activity for $E_{\mathrm{III}}, \mathrm{S} 15$ and S19 strains comparable to the other isolates. However, some strains $E_{\mathrm{A}}, E_{\mathrm{B}}$ and $E_{\mathrm{D}}$ did not show emulsification activity, which was probably due to their inability to emulsify a complete crude oil but likely one of its fractions. Isolated 
Table 4 Some biochemical characteristics of the hydrocarbon-degrading bacteria strains

\begin{tabular}{|c|c|c|c|c|c|c|}
\hline Isolate & Colony size, color, form & Cell shape and arrangement & Gram staining & Oxidase & Motility & Spore formation \\
\hline$E_{\mathrm{A}}$ & NP, yellowish, round & Isolated bacillus & $\mathrm{N}$ & ND & - & - \\
\hline$E_{\mathrm{B}}$ & NP, off-white, irregular & Isolated rods & $\mathrm{N}$ & ND & - & - \\
\hline$E_{\mathrm{D}}$ & $\mathrm{NP}$, cream, round & Serial bacillus & $\mathrm{N}$ & ND & & - \\
\hline$E_{\mathrm{F}}$ & $\mathrm{NP}$, cream, irregular & Isolated cocci & $\mathrm{N}$ & ND & - & - \\
\hline$E_{\mathrm{III}}$ & $\mathrm{NP}$, cream, round & Isolated or serial bacillus & $\mathrm{N}$ & ND & - & - \\
\hline $\mathrm{S} 13$ & $\mathrm{NP}$, white, round & Isolated or chained rods & $\mathrm{N}$ & ND & + & - \\
\hline $\mathrm{S} 14$ & $\mathrm{NP}$, white, round & Isolated or duplicated & $\mathrm{N}$ & ND & + & - \\
\hline $\mathrm{S} 15$ & $\mathrm{NP}$, white, irregular & Isolated or serial bacillus & $\mathrm{N}$ & ND & - & ND \\
\hline $\mathrm{S} 17$ & $\mathrm{NP}$, white, round & Cocci, isolated or in duplicate & $\mathrm{N}$ & ND & - & - \\
\hline $\mathrm{S} 18$ & $\mathrm{NP}$, beige, round & Isolated or duplicated coccobacillus & $\mathrm{N}$ & + & + & - \\
\hline S19 & $\mathrm{NP}$, yellow, round & Isolated or serial rods & $\mathrm{N}$ & ND & + & ND \\
\hline $\mathrm{S} 20$ & NP, off-white, round & Cocci in clusters & $\mathrm{N}$ & + & - & - \\
\hline $\mathrm{S} 21$ & $\mathrm{NP}$, beige, irregular & Bacillus in clusters & $\mathrm{N}$ & ND & + & - \\
\hline $\mathrm{S} 22$ & NP, off-white, irregular & Bacillus in clusters & $\mathrm{N}$ & ND & + & - \\
\hline $\mathrm{S} 23$ & $\mathrm{NP}$, yellow, round & Isolated or duplicated bacillus & $\mathrm{N}$ & ND & + & - \\
\hline
\end{tabular}

$N P$ non-punctiforme, $N$ Gram negative, $P$ Gram positive, + positive response, - negative response, $N D$ not defined

Table 5 Emulsification activity and oil spreading values for the isolated strains

\begin{tabular}{lll}
\hline Isolate & $\begin{array}{l}\text { Emulsification activity } \\
\text { oil spreading (E24 \%) }\end{array}$ & $\begin{array}{l}\text { Oil spreading (area } \\
\text { of oil displaced in } \\
\mathrm{mm})(\mathrm{mm})\end{array}$ \\
\hline
\end{tabular}

\begin{tabular}{lll}
\hline Control & 0 & 0 \\
$E_{\mathrm{A}}$ & 0 & 0 \\
$E_{\mathrm{B}}$ & 0 & 0 \\
$E_{\mathrm{D}}$ & 0 & 0 \\
$E_{\mathrm{F}}$ & 31 & 35 \\
$E_{\mathrm{III}}$ & 49 & 33 \\
$\mathrm{~S} 13$ & 58 & 40 \\
$\mathrm{~S} 14$ & 51 & 39 \\
$\mathrm{~S} 15$ & 44 & 28 \\
$\mathrm{~S} 17$ & 56 & 40 \\
$\mathrm{~S} 18$ & 76 & 55 \\
$\mathrm{~S} 19$ & 46 & 31 \\
$\mathrm{~S} 20$ & 72 & 60 \\
$\mathrm{~S} 21$ & 66 & 50 \\
$\mathrm{~S} 22$ & 65 & 49 \\
$\mathrm{~S} 23$ & 48 & 35 \\
\hline
\end{tabular}

All data reported in this table is the mean of three values, and cited value in the table is standard deviation

HDB oil emulsification properties are the result of bioemulsifiant production molecules. It is known that HDB release surfactants or emulsifiers in order to facilitate assimilation of insoluble substrates such as crude oil (Bucheli-Witschel and Egli 2010); indeed, biosurfactants are structurally diverse amphiphiles that are secreted in the environment to facilitate the diffusion and uptake by microorganisms of hydrophobic substances from aqueous media (Lawniczak et al. 2013). Biosurfactant-producing microbes are found in various ecosystems, especially in those polluted with hydrophobic contaminants, such as petroleum wastes which are more yielding than undisturbed environments (Belcher et al. 2012; She et al. 2011). The bioavailability of petroleum products to microorganisms of oil-degrading community is considerably affected by biosurfactants, which isolate individual petroleum molecules in micelles (Belcher et al. 2012). Chemical surfactants have shown their efficiency in enhanced washing processes to diminish metal, salts and hydrocarbon contents in drilling muds (Torres et al. 2003; Childs et al. 2005; Fernandez et al. 2008), but the use of natural surfactants in remediation, even if probably less quick, has the advantage to be efficient without ecotoxicologial impact.

\section{Conclusion}

The studied drilling quagmire represents a suitable environment for microbial life, and the richness in different mineral and organic elements of the drilling oily sludge promotes bacterial growth and diversity. Fifteen bacterial strains were isolated, which showed a high capacity to emulsify crude oil for some of them, with a good emulsification index (between 31 and $76 \%$ ) and large clear zone displacement oil (in the range $28-60 \mathrm{~mm}$ ). This finding proves bioavailability of different mineral elements and water-insoluble substrates by emulsification through drilling mud indigenous HDB. Oil field 


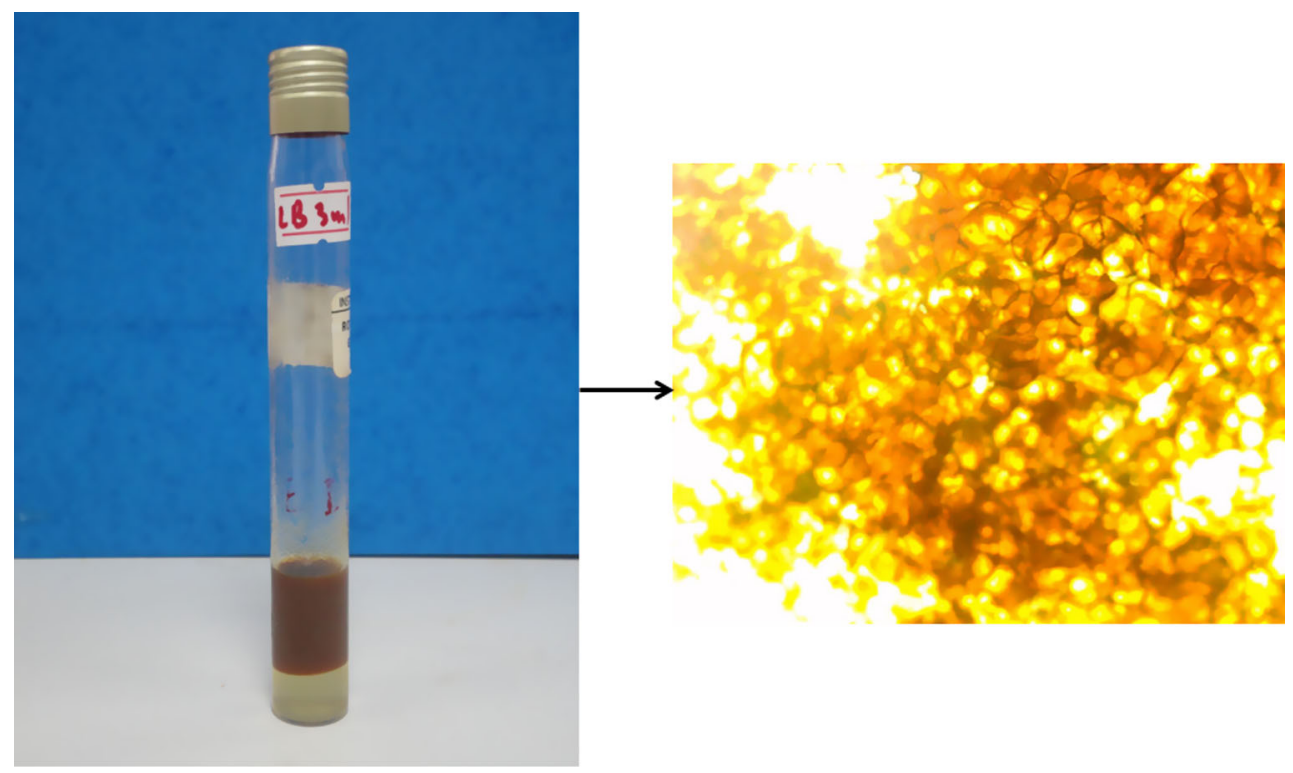

Fig. 2 Visual and microscopic $(\times 100)$ observations of the emulsion formed by the S18 strain

quagmires may provide, owing to their autochthone HDB microflora, possible solutions for bioremediation of polluted environments; they represents a high efficiency and low-cost processes, representing an extremely important way to restore contaminated areas among several other cleanup techniques. It is likely that assessment tests are needed to determine which biotechnological process is the most suitable for a given environment, given the large pollutant categories in the petroleum industry and that indigenous bacteria could produce more appropriate products, for local conditions than commercial bioremediation products.

Acknowledgments We wish to thank Dr. Annette Bourgeois for the English reviewing of the manuscript and Ms. Djamila Maatalah from Sonatrach for the technical help.

\section{References}

Abbasnezhad H, Gray M, Foght JM (2011) Influence of adhesion on aerobic biodegradation and bioremediation of liquid hydrocarbons. Appl Microbiol Biotechnol 92:653-675

AFNOR. Norme Française NF T 90-114 (1979) Testing water: determination of total hydrocarbons infra-red spectrophotometric method

AFNOR. Norme Française NF T 90-019 (1984) Dosage du sodium et du potassium. Méthode par spectrométrie d'émission de flamme

AFNOR. Norme Française NF X 31-210 (1993) Déchets: Essai de lixiviation

AFNOR. Norme Française NF EN 12457-2 (2002) Characterization of waste. Leaching. Compliance test for leaching of granular waste materials and sludges. Part 2: one stage batch test at a liquid to solid ratio of $10 \mathrm{l} / \mathrm{kg}$ for materials with particle size below $4 \mathrm{~mm}$ (without or with size reduction)
Agwa A, Leheta H, Salem A, Sadiq R (2013) Fate of drilling waste discharges and ecological risk assessment in the Egyptian Red Sea: an aquivalence-based fuzzy analysis. Stoch Environ Res Risk Assess 27:169-181

Atagana HI (2008) Compost bioremediation of hydrocarbon-contaminated soil inoculated with organic manure. Afr $\mathrm{J}$ Biotechnol $7(10): 1516-1525$

Baba Hamed S (2013) Controlling environmental pollution resulting from the products used in drilling muds. Int J Emerg Technol Res 1(1):1-7

Bamforth SM, Singleton I (2005) Bioremediation of polycyclic aromatic hydrocarbons: current knowledge and future directions. J Chem Technol Biotechnol 80(7):723-736

Banat IM (1995) Biosurfactants production and use in microbial enhanced oil recovery and pollution remediation: a review. Bioresour Technol 51(1):1-12

Banat IM, Franzetti A, Gandolfi I, Bestetti G, Martinotti MG, Fracchia L, Smyth TJ, Marchant R (2010) Microbial biosurfactants production: applications and future potential. Appl Microbiol Biotechnol 87(2):427-444

Belcher RW, Huynh KV, Hoang TV, Crowley DE (2012) Isolation of biosurfactant-producing bacteria from the Rancho La Brea Tar Pits. World J Microbiol Biotechnol 28(12):3261-3267

Beskoski VP, Gojgic-Cvijovic G, Milic J, Ilic M, Miletic S, Solevic T, Vrvic MM (2011) Ex-situ bioremediation of a soil contaminated by mazut (heavy residual fuel oil) - a field experiment. Chemosphere 83:34-40

Bidoia ED, Montagnolli RN, Lopes PRM (2010) Microbial biodegradation potential of hydrocarbons evaluated by colorimetric technique: a case study. In: Mendez-Vilas A (ed) Current research, technology and education topics in applied microbiology and microbial biotechnology, vol 2. FORMATEX, Badajoz, pp 1277-1288

Bucheli-Witschel M, Egli T (2010) Growth of hydrocarbon-degrading bacteria in continuous culture. In: Timmis KN (ed) Handbook of hydrocarbon and lipid microbiology. Springer, Berlin, pp 3529-3543

Buekers, J. (2007). Fixation of cadmium, copper, nickel and zinc in soil: kinetics, mechanisms and its effect on metal bioavailability. 
Ph.D. thesis of University, Catholic University of Leuven, Leuven

Bushnell LD, Haas HF (1941) The utilization of certain hydrocarbons by microorganisms. J Bacteriol 41(5):653-673

Caenn R, Darley HCH, Gray GR (2011) Introduction to drilling fluids. In: Caenn R, Darley HCH, Gray GR (eds) Composition and properties of drilling and completion fluids, 6th edn. Gulf professional Publishing, Elsevier Inc, Houston, pp 1-37

Calvo C, Silva-Castro GA, Uad I, García Fandiño C, Laguna J, González-López J (2008) Efficiency of the EPS emulsifier produced by Ochrobactrum anthropiin different hydrocarbon bioremediation assays. J Ind Microbiol Biotechnol 35(11): 1493-1501

Chandra S, Sharma R, Singh K, Sharma A (2013) Application of bioremediation technology in the environment contaminated with petroleum hydrocarbon. Ann Microbiol 63(2):417-431

Childs JD, Acosta E, Scamerhorn JF, Sabatini DA (2005) Surfactantenhanced treatment of oil-based drill cuttings. J Energy Res Technol 127(2):153-162

Claus D, Fritze D, Kocur M (2006) Genera related to the genus Bacillus, Sporolactobacillus, Sporosarcina, Planococcus, Filibacter and Caryophanon. In: Balows A, Truper HG, Dworkin M, Harder W, Schleifer KH (eds) The prokaryotes, 2nd edn. Fischer-Verlag, New York, pp 1769-1791

Cooper DG, Goldenberg BG (1987) Surface-active agents from two Bacillus species. Appl Environ Microbiol 53(2):224-229

Déziel E, Paquette G, Villemur R, Lépine F, Bisaillon JG (1996) Biosurfactant production by a soil Pseudomonas strain growing on polycyclic aromatic hydrocarbons. Appl Environ Microbiol 62(6): 1908-1912

Doyle AB, Pappworth SSR, Caudle DD (2008) Drilling and production discharges in the marine environment. In: Orszulik ST (ed) Environmental technology in the oil industry. Springer, Dordrecht, pp 155-187

Egazar'yants SV, Vinokurov VA, Vutolkina AV, Talanova MY, Frolov VI, Karakhanov EA (2015) Reviews: oil sludge treatment processes. Chem Technol Fuels Oils 51(5):506-515

Escobar LF, Vredenburg H (2011) Multinational oil companies and the adoption of sustainable development: a resource-based and institutional theory interpretation of adoption heterogeneity. J Bus Ethics 98(1):39-65

FD T90-112 (1998) Qualité de l'eau: dosage de huit éléments métalliques ( $\mathrm{Mn}, \mathrm{Fe}, \mathrm{Co}, \mathrm{Ni}, \mathrm{Cu}, \mathrm{Zn}, \mathrm{Ag}, \mathrm{Pb}$ ) par spectrométrie d'absorption atomique dans la flamme

Fernandez LC, Zegarra H, Baca G, Torres LG (2008) Characterization and surfactant-enhanced washing treatability of drilling fluids stored for more than 20 years. J Surfact Deterg 11(4):307-314

Foght J, Aislabie J (2005) Enumeration of soil microorganisms, soil biology. In: Margesin R, Schinner F (eds) Manual for soil analysis, vol 5. Springer, Berlin, pp 261-280

Gerhardt P, Costilow RN, Murray RGE, Nester EW, Briggs Phillips G, Wood WA (1981) Manual of methods for general bacteriology. American Society for Microbiology, Washington

Götte T, Richter DK (2007) Cathodoluminescence characterization of quartz particles in mature arenites. Sedimentology 53:1347-1359

Huesemann MH (1994) Guidelines for the development of effective statistical soil sampling strategies for environmental applications. In: Calabrese EJ, Kostecki PT (eds) Hydrocarboncontaminated soils and groundwater. Lewis, Boca Raton, pp 47-96

Iqbal S, Khalid ZM, Malk KA (1994) Enhanced biodegradation and emulsification of crude oil and hyperproduction of biosurfactant by a gamma ray-induced mutant of Pseudomonas aeruginosa. Lett Appl Microbiol 21(3):176-179
ISO 10390 (2005) Soil quality determination of pH. International Standard Organisation, Geneva

ISO 10694 (1995) Soil quality: determination of organic and total carbon after dry combustion (elementary analysis). International Standard Organisation, Geneva

ISO 11461 (1997) Soil quality: determination of water content on a volume basis gravimetric method. International Standard Organisation, Geneva

ISO 5667-13 (1997) Water quality: sampling. Part 13: guidance on sampling of sludges from sewage and water treatment works. International Standard Organisation, Geneva

Johannes KF (2012) Drilling Muds. Petroleum engineer's guide to oil field chemicals and fluids. Gulf Professional Publishing, Oxford, pp 1-59

Kang SW, Kim YB, Shin JD, Kim EK (2010) Enhanced biodegradation of hydrocarbons in soil by microbial biosurfactant, sophorolipid. Appl Biochem Biotechnol 160(3):780-790

Korol VV, Pozdnyshev GN, Manyrin VN (2005) Utilization of waste products upon drilling operations. Ekolog. Promyshlennost' Rossii 1:40-42

Lawniczak L, Marecik R, Chrzanowski L (2013) Contributions of biosurfactants to natural or induced bioremediation. Appl Microbiol Biotechnol 97(6):2327-2339

Li XG, Lv Y, Ma BG, Jian SW, Tan HB (2011) Influence of sintering temperature on the characteristics of shale brick containing oil well-derived drilling waste. Environ Sci Pollut Res 18:1617-1622

Mansurov ZA, Ongarbaev EK, Tuleutaev BK (2001) Ecology: contamination of soil by crude oil and drilling muds: use of wastes by production of road construction materials. Chem Technol Fuels Oils 37(6):141-143

McDonald JA, Portier R (2003) Feasibility studies on in situ biological treatment of drilling muds at an abandoned site in Sicily. J Chem Technol Biotechnol 78:709-716

Minai-Tehrani D, Herfatmanesh A (2007) Biodegradation of aliphatic and aromatic fractions of heavy crude oil-contaminated soil, a pilot study. Bioremediation J 11(2):71-76

Mohanty S, Mukherji S (2012) Alteration in cell surface properties of Burkholderia spp. during surfactant-aided biodegradation of petroleum Hydrocarbons. Appl Microbiol Biotechnol 94(1):193-204

Nanekar S, Dhote M, Kashyap S, Singh SK, Juwarkar AA (2015) Microbe assisted phytoremediation of oil sludge and role of amendments: a mesocosm study. Int J Environ Sci Technol 12(1):193-202

NF ISO 11464 (X31-412) (2006) Soil quality: pretreatment of samples for physicochemical analysis

NF EN ISO 7980 (2000) Water quality: determination of calcium and magnesium. Atomic absorption spectrometric method

NF X 31147 (1997) Qualité Des Sol: Sols, Sédiments. Mise en solution totale par attaque acide

Normand P, Caumette P, Goulas P, Pujic P, Wisniewski-Dye F (2015) Microbial habitats: diversity, adaptation and interactions adaptations of prokaryotes to their biotopes and to physicochemical conditions in natural or anthropized environments. In: Bertrand JC, Caumette P, Lebaron P, Matheron R, Normand P, SimeNgando $\mathrm{T}$ (eds) Environmental microbiology: fundamentals and applications-microbial ecology. Springer, Dordrecht, pp 293-351

Osman KT (2014) Soil pollution. Soil degradation, conservation and remediation. Springer, Dordrecht, pp 149-226

Overmann J (2013) Principles of enrichment, isolation, cultivation and preservation of prokaryotes. In: Rosenberg E, Belong E, Lory S, Stackebrandt E, Thompson F (eds) The prokaryotes. Springer, Berlin, pp 149-207 
Ramirez D, Dussan J (2014) Landfarmed oil sludge as a carbon source for Canavalia ensiformis during phytoremediation. Int $\mathbf{J}$ Environ Sci Technol 11(5):1197-1206

Reyes-Avila J, Roldàn-Carrillo T, Castorena-Cortés G, ZapataPeñasco I, Olguín-Lora P (2013) Effect of sulphur species on the hydrocarbon biodegradation of oil sludge generated by a gas processing facility. Int J Environ Sci Technol 10:551-558

Semple KT, Morris AWG, Paton GI (2003) Bioavailability of hydrophobic organic contaminants in soils: fundamental concepts and techniques for analysis. Eur J Soil Sci 54:809-818

Shagut RY, Ignat'ev LA (2012) Plant reaction to drilling wastes of petroleum complex in the zone of middle Taiga of Ob Region. Contemp Probl Ecol 5(2):229-233

She YH, Zhang F, Xia JJ, Kong SQ, Wang ZL, Shu FC, Hu JM (2011) Investigation of biosurfactant-producing indigenous microorganisms that enhance residue oil recovery in an oil reservoir after polymer flooding. Appl Biochem Biotechnol 163(2):223-234

Shperber ER, Bokovikova TN, Shperber DR (2011) Analytical review: methods for processing petroleum wastes. Chem Technol Fuels Oils 47(3):237-242

Singh A, Owen WP, Kuhad Ramesh C (2005) Feasibility studies for microbial remediation hydrocarbon-contaminated soil. In: Margesin R, Schinner F (eds) Soil biology, manual for soil analysis, vol 5. Springer, Berlin, pp 131-153

Smagin AV, Koltsov IN, Pepelov IL, Kirichenko AV, Sadovnikova NB, Kinzhaev RR (2011) The physical state of finely dispersed soil-like systems with drilling sludge as an example. Eur Soil Sci 44(2):163-172

Torres LG, Orantes JL, Iturbe R (2003) Critical micellar concentrations for three surfactants and their diesel-removal efficiencies in petroleum-contaminated soils. Environ Geosci 10(1):1-9
Touraud E, Roussy J, Domeizel M, Junqua G, Thomas O (2007) Leachates and organic extracts from solids. In: Thomas $\mathrm{O}$, Burgess $\mathrm{C}$ (eds) Techniques and instrumentation in analytical chemistry, UV-visible spectrophotometry of water and wastewater, vol 27. Elsevier, Amsterdam, pp 243-265

Vecchili GI, Delpanno MT, Painceira MT (1990) Use of selected autochthonous soil bacteria to enhance degradation of hydrocarbons in soils. Environ Pollut 67(3):249-258

Wang D, Zhang W, Zhang X, Zhao G, Zuo R, Ni J, Yang G, Jia J, Yang K, Zhu Y, Xie W, Zhu W, Zhang P, Fan L, Ye J, Wang Y (2015) Drilling fluids and solids control technology. In: The China continental scientific drilling project. Springer Geology. Springer, Berlin, pp 273-302

Wesp HF, Tang X, Edenharder R (2000) The influence of automobile exhausts on mutagenicity of soil: contamination with, fractionation, separation and preliminary identification of mutagens in the Salmonella/reversion assay and effects of solvent fractions on the sister chromatid exchange in human lymphocyte cultures and in the in vivo mouse bone marrow micronucleus assay. Mutat Res 472(1-2):1-21

Wojtanowicz AK (2016) Environmental control of drilling fluids and produced water. In: Orszulik S (ed) Environmental technology in the oil industry. Springer, Netherlands, pp 77-121

Yadav BK, Shrestha SR, Hassanizadeh SM (2012) Biodegradation of toluene under seasonal and diurnal fluctuations of soil-water temperature. Water Air Soil Pollut 223(7):3579-3588

Youssef NH, Duncan KE, Nagle DP, Savager KN, Knapp RM, Mc Inerney MJ (2004) Comparison of methods to detect biosurfactant production by diverse microorganisms. J Microbiol Methods 56:339-346 